\title{
Strategi Pemasaran Produk Makanan Catering \\ Melalui Media Sosial Instagram
}

by

\author{
Wayan Budi Mahardhika ${ }^{(1)}$ \\ Ni Nyoman Sunariani ${ }^{(2)}$ \\ Dinas Pekerjaan Umum Kab. Klungkung ${ }^{(1)}$ \\ Universitas Pendidikan Nasional ${ }^{(2)}$ \\ budimahardhikawayan@gmail.com ${ }^{(1)}$ \\ nyomansunariani@ymail.com ${ }^{(2)}$
}

\begin{abstract}
This study examines how marketing strategies are carried out by Catering businesses in Denpasar Bali. The use of social media as effective marketing is also felt and tried by all businesses, ranging from food, clothing and banking businesses.

The use of social media is based on the rapid development of smart devices in which utilization is already very common and well known with everyone. Marketing strategies through social media like Instagram are also very often heard, especially people who are still productive. There are many examples of the use of social media to promote a product. With only a digital smart device and internet data package, everyone can access and also market their merchandise there.

Instagram is very good to use because it relies on images as the main attraction, it is also equipped with the facilities to write comments and also short direct messages making Instagram a favorite in social media, especially for young people. The catering business also want to use Instagram. As this research was made, the four catering respondents selected based on the more than 1000 of followers are: Chika Catering, Catering Kerti Catering, Warung Umi Catering and Tunjung Asri Catering, have positive answer with the presence of this Instagram. Discussions using Marketing Mix show positive results in using Instagram to market their products
\end{abstract}

Keyword : Marketing Strategy, Social Media, Instagram, Marketing Mix, Catering

\section{Business}


Tujuan penelitian ini untuk mengetahui strategi pemasaran dilakukan oleh bisnis Catering di Denpasar Bali. Pemanfaatan media sosial sebagai strategi pemasaran yang efektif bagi semua bisnis, mulai dari bisnis makanan, pakaian, perbankan dan jasa lain nya.

Pemanfaatan media sosial didasari oleh berkembang pesat nya generasi milenial yang dimana pemanfaatan nya sudah sangat lumrah bagi siapa saja. Strategi pemasaran melalui media sosial seperti Instagram sangat familiar bagi generasi milenial, terutama masyarakat yang lahir setelah tahun 1990. Banyak penggunaan media sosial sebagai promosi suatu produk. Merupakan salah satu budaya masyarakat modern yang lebih praktis dalam mengakses segala hal melalui gawai pintar nya masing-masing.

Instagram merupakan contoh nyata membuat pemasaran menjadi semakin menarik, semakin baik dan semakin praktis. Dengan bermodalkan gawai pintar digital dan paket data internet, masyarakat sudah bisa mengakses dan juga memasarkan barang dagangan nya disana. Instagram sangat baik digunakan karena mengandalkan gambar sebagai daya tarik utama, juga dilengkapi dengan fasilitas menulis komentar dan juga pesan langsung singkat menjadikan Instagram menjadi favorit di sosial media terutama anak muda. Bisnis catering juga seperti tidak mau kalah untuk memanfaatkan media sosial Instagram, sebagaimana penelitian ini dibuat, responden empat catering yang dipilih berdasarkan jumlah follower lebih dari 1000 ini yaitu : Chika Catering, Boga Kerti Catering, Warung Umi Catering dan Tunjung Asri Catering, memiliki jawaban yang positif dengan kehadiran dari sosial media Instagram ini. Pembahasan menggunakan Bauran Pemasaran atau Marketing Mix menunjukan hasil yang positif dalam penggunaan Instagram untuk pemasaran produk mereka.

Kata kunci: Strategi Pemasaran, Media Sosial, Instagram, Marketing Mix, Bisnis Catering 


\section{PENDAHULUAN}

Era globalisasi merupakan era yang penuh dengan kecepatan transaksi, kemajuan teknologi, manusia sebagai konsumen akan dimanjakan dengan teknologi yang ada di sekitar nya. Kemajuan teknologi ini juga merambah bisnis menjadi lebih impresif semakin bertambah nya tahun. Karena perkembangan teknologi ini tidak akan pernah berhenti sampai disini saja (Darma, dkk., 2019). Kemajuan hardware dan software kita akan terus berkembang. Seakan tidak puas akan kemampuan teknologi saat ini, perubahan teknologi menjadi lebih praktis dan hebat. Perubahan yang sangat drastis dalam bidang ICT (Information Communication and Technology) juga merambah di dunia pemasaran. Pemasaran yang biasa nya menggunakan cara konvensional, sudah mulai menggunakan habat nya kemajuan teknologi dalam berdagang, tentu nya untuk menjamah lebih jauh lagi pelanggan yang tidak terjamah sebelum nya (Darma, 2019). Ketatnya persaingan di bisnis lokal maupun global maka diperlukan nya persaingan untuk menjadi yang terbaik yaitu keunggulan bersaing (competitive advantage) agar mampu memenangkan persaingan di jaman sekarang ini. Karena itu para pemasar harus menerapkan konsep pemasaran modern yang berorientasi pasar atau pelanggan karena mereka merupakan ujung tombak keberhasilan pemasaran (Kotler, 2004; Darma, 2018).

Bisnis Catering merupakan bisnis yang sangat menjanjikan. Makanan yang menjadi produk utama dari bisnis catering memerlukan promosi yang besar untuk menjadikan bisnis catering lancar. Penjualan dari mulut ke mulut (Mouth to mouth) yang biasanya dilakukan tidak bisa menjaring konsumen terlalu luas, karena cakupan nya lokal dan kerabat saja (Darma, 2019). Namun dengan adanya media sosial yang mengandalkan foto yang menarik, maka seharus nya pengguna catering juga akan memanfaatkan ini untuk bisa menjaring pelanggan lebih banyak lagi. Bisnis catering sudah sangat menjamur di Indonesia. Bisnis ini terbilang cukup menjanjikan dan mampu menjaring banyak tenaga kerja di sekitar nya (Maharani dan Darma, 2018). Tenaga kerja yang akan terserap antara lain adalah tukang masak atau koki , tukang cuci piring, supplier makanan mentah dan segar, petani bahan baku makanan dan juga jasa transportasi. Bisnis ini mengandung multiplayer effect yang sangat menjanjikan apabila dikelola dengan baik. Di denpasar sangat banyak ditemukan bisnis catering,. Mulai yang skala kecil, menengah ataupun sudah besar. Terletak di jantung kota Denpasar maka akan memudahkan untuk memobilisasi bahan makanan dan makanan jadi ke seluruh pelosok Bali. Bisa dikatakan pula bisnis ini sudah mulai menjamur di Bali (Setyawati dan Darma, 2018). Namun perubahan jaman yang begitu pesat maka persaingan juga akan semakin ketat dan melakukan cara baru untuk menarik jumlah pelanggan semakin banyak lagi. Dengan adanya 
smartphone dan media sosial, maka seharus nya fenomena ini akan dimanfaatkan oleh pebisnis makanan catering untuk mempromosikan produk mereka di dunia maya dengan harapan akan menjaring lebih banyak lagi konsumen.

\section{TINJAUAN PUSTAKA}

\section{Strategi Pemasaran}

Pemasaran adalah suatu proses sosial dan manajerial yang didalam individu dan kelompok mendapatkan apa yang mereka butuhkan dan inginkan dengan menciptakan, menawarkan, dan mempertukarkan produk yang bernilai dengan pihak lain (Kotler, 2004:7; Handika, Maradona, dan Darma, 2018; Adnyana dan Darma, 2015). Pemasaran adalah suatu proses yang melibatkan kegiatan-kegiatan penting yang memungkinkan individu dan perusahaan mendapatkan apa yang mereka butuhkan dan inginkan melalui pertukaran dengan pihak lain (Boyd, 2000:4; Kusnadi dan Darma, 2018; Kanten dan Darma, 2017).

\section{Marketing Mix (Bauran Pemasaran)}

Menurut Kotler dan Amstrong (2012:92); Darma (2006), "Marketing mix is good marketing tools, is a set of product, pricing, promotion, distribution combine to produce the desire response of the target market”. Bauran pemasaran atau disebut dengan Marketing Mix adalah kumpulan variabel-variabel yang dapat dipergunakan perusahaan untuk memepengaruhi tanggapan konsumen. Kata lain nya ini merupakan strategi pemasaran yang mutlak dilakukan untuk menawarkan suatu produk. Variabel-variabel yang dapat mempengaruhi pembeli adalah yang disebut 7P (Product, Price, Place, Promotion, Process, People, dan Physical Evidence).

\section{Media Sosial}

Menurut Caleb \& Rebecca (2015) dan Arsriani \& Darma (2013) mengatakan bahwa media sosial adalah media berbasis Internet yang memungkinkan pengguna berkesempatan untuk berinteraksi dan mempresentasikan diri, baik secara seketika ataupun tertunda, dengan khalayak luas maupun tidak yang mendorong nilai dari user-generated content dan persepsi interaksi dengan orang lain. 


\section{Media Sosial Instagram}

Instagram menurut Bambang (2012:53) ; Agung dan Darma (2019) menyatakan bahwa nama Instagram berasal dari kata 'Insta' yang berarti instan atau cepat dan 'Gram' yang berarti pesan diambil dari kata 'Telegram'. Inti dari penamaan ini adalah media sosial yang instan bisa mengirimkan pesan kepada lawan komunikasi nya. Menurut Bambang dalam buku nya yang berjudul Instagram Handbook yang menyatakan indikator dari media sosial Instagram adalah Hashtag, Geotag , Follow, Like, Share, Komentar dan Mention .

\section{Bisnis Catering}

Catering bermula dari sebutan to cater yang berisi terjemahan bebasnya berarti buat persiapan dan menyajikan makanan dan minuman buat umum. Seseorang yang buat persiapan dan menyajikan makanan dan minuman itu disebut caterer. Industri jasa makanan (katering industri) meliputi daerah-daerah, institusi beserta perusahaan yang memberikan makanan. Industri ini meliputi restoran, sekolah beserta kafetaria tempat tinggal sakit, operasi katering, beserta banyak format lainnya, juga 'on-premises' beserta 'off-premises' caterings. Catering yakni segmen multifaset penyajian makanan industri tersedia banyak bentuk usaha katering dalam segmen katering. Industri jasa makanan digolongkan jadi tiga klasifikasi umum yaitu segmen komersial, segmen nonkomersial, beserta segmen militer. Manajemen katering bisa jadi didefinisikan sebagai tugas perencanaan, pengorganisasian, pengendalian dan mengeksekusi. 


\section{Kerangka Pemikiran}

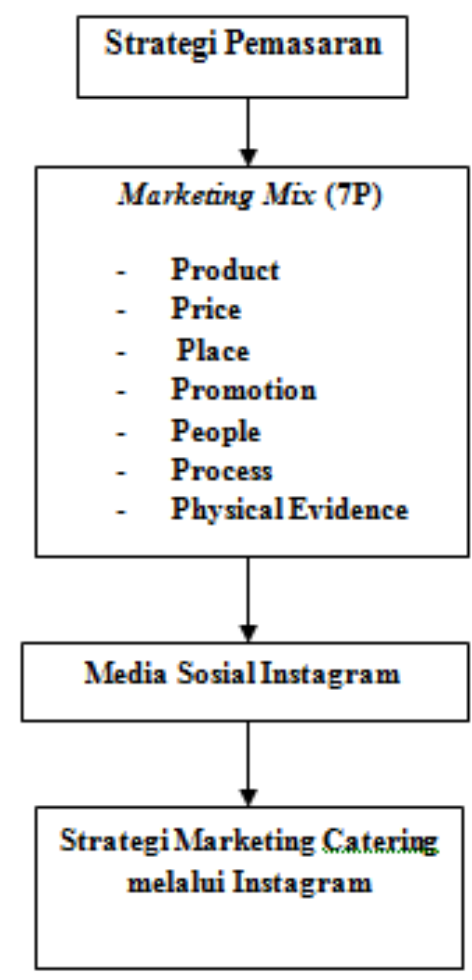

\section{Gambar 1 : Kerangka Pemikiran Strategi Pemasaran Produk Makanan Catering menggunakan Sosial Media Instagram di Denpasar Bali}

\section{METODE PENELITIAN}

Lokasi penelitian yang akan menjadi tempat penelitian ini adalah di Denpasar Bali. Pemilihan kota Denpasar adalah karena Denpasar merupakan Ibu kota dari Provinsi Bali yang dimana hampir bisnis apa saja pasti ada di Denpasar, termasuk bisnis catering yang paling berkembang pesat di Kota Denpasar ini. Pemilihan informan dilakukan dengan menggunakan metode purposive sampling dimana informan yang dipilih dianggap memenuhi kriteria tertentu dari peneliti, sehingga data yang diberikan oleh informan merupakan data yang tepat, akurat, mencukupi, dan sesuai seperti yang diharapkan peneliti. Penelitian ini menggunakan 4 informan yang diambil dari akun Instagram catering yang sudah memiliki 1000 followers yaitu Boga Kerti Catering, Warung Umi Catering, Tunjung Asri Catering dan Chika Catering.

Data yang dikumpulkan menggunakan instrumen wawancara yang mendalam. Wawancara adalah metode pengumpulan data dengan cara tanya jawab pada responden dimana jawaban responden ditulis atau dicatat (Sugiyono, 2001 dan Darma, 2004). Miles dan Huberman dalam Sugiyono (2010) mengemukakan, bahwa aktivitas dalam analisis data kualitatif dilakukan secara interaktif dan berangsung secara terus menerus sampai tuntas 
sehingga data sudah jenuh.Aktivitas dalam analisis yaitu; reduksi data (data reduction), penyajian data (display), dan menarik kesimpulan atau verifikasi (conclucing drawing/verivication)

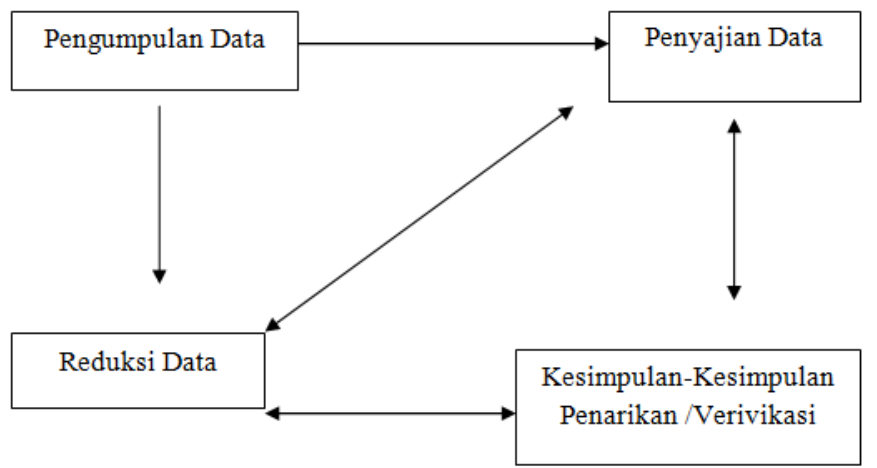

\section{PEMBAHASAN}

1. Bagian ini membahas tentang segmen Product dari Tunjung Asri Catering atau juga bisa diartikan adalah pembahasan mengenai hal apa saja yang dihasilkan oleh catering tersebut. Produk unggulan dari Tunjung Asri Catering, Chika Catering, Boga Kerti Catering dan juga Warung Umi Catering adalah berupa makanan prasmanan, nasi kotak dan juga snack, juga tersedia nasi tumpeng yang dikhususkan untuk kustomer yang memiliki hajatan adat. Yang membedakan dari ke empat catering tersebut adalah inovasi dan cita rasa yang ditimbulkan untuk menarik minat orang membeli karena dikenal lezat dan juga pelayanan maksimal.

2. Harga yang ditawarkan dalam catering Tunjung Asri, untuk masakan prasmanan ada 5 Jenis, mulai dari harga 35 ribu rupiah, 45 ribu rupiah, 55 ribu rupiah, 65 ribu rupiah dan juga paling mahal ada di angka 75 ribu rupiah per porsi. Harga perporsi sudah termasuk dengan pelayan, meja, hiasan, air mineral/jus, dan juga krupuk dan sambal. Untuk prasmanan biasanya dipatok dengan minimal pesanan sebanyak 200 porsi. Apabila ada pesanan dari luar daerah, maka akan dikenakan biaya transport tergantung dari daerah nya. Untuk pemesanan nasi kotak juga ada di harga 25 ribu rupiah perkotak nya dan pemesanan Nasi Tumpeng dengan harga 400 ribu rupiah.

Harga yang ditawarkan dalam catering Boga Kerti untuk masakan prasmanan ada 4 Jenis makanan, mulai dari harga 40 ribu rupiah, 50 ribu rupiah, 60 ribu rupiah dan juga paling mahal ada di angka 75 ribu rupiah per porsi. Harga perporsi sudah termasuk dengan pelayan, air mineral, dan juga krupuk dan sambal. Unutk meja dan dekorasi 
tidak menyediakan karena Boga Kerti Catering berpengalaman di tata hidangan saja, bukan ke tata meja dan dekorasi nya. Untuk prasmanan biasanya dipatok dengan minimal pesanan sebanyak 100 porsi. Apabila ada pesanan dari luar daerah, maka akan dikenakan biaya transport tergantung dari daerah nya. Untuk pemesanan nasi kotak juga ada di harga 25 ribu rupiah perkotak nya dan pemesanan Nasi Tumpeng dengan harga 420 ribu rupiah.

Harga yang ditawarkan dalam catering Chika Catering hampir sama dengan Tunjung Asri Catering. Adapun untuk masakan prasmanan ada 5 Jenis, mulai dari harga 35 ribu rupiah, 45 ribu rupiah, 55 ribu rupiah , 65 ribu rupiah dan juga paling mahal ada di angka 75 ribu rupiah per porsi. Harga perporsi sudah termasuk dengan pelayan, meja , hiasan, air mineral, ice cream cup kecil, dan juga krupuk dan sambal. Untuk prasmanan biasanya dipatok dengan minimal pesanan sebanyak 250 porsi. Apabila ada pesanan dari luar daerah, maka akan dikenakan biaya transport tergantung dari daerah nya. Untuk pemesanan nasi kotak juga ada di harga 25 ribu rupiah perkotak nya dan pemesanan Nasi Tumpeng dengan harga 400 ribu rupiah.

Harga yang ditawarkan dalam catering Warung Umi untuk masakan prasmanan ada 4 Jenis, mulai dari harga 35 ribu rupiah, 45 ribu rupiah, 55 ribu rupiah dan 65 ribu rupiah per porsi. Harga perporsi sudah termasuk dengan meja, air mineral/jus, dan juga krupuk dan sambal. Untuk prasmanan biasanya dipatok dengan minimal pesanan sebanyak 300 porsi. Apabila ada pesanan dari luar daerah, maka akan dikenakan biaya transport tergantung dari daerah nya. Untuk pemesanan nasi kotak juga ada di harga 25 ribu rupiah perkotak nya dan pemesanan Nasi Tumpeng dengan harga 500 ribu rupiah skala sedang.

3. Tempat yang ada di Tunjung Asri Catering, Boga Kerti Catering, Chika Catering dan juga Warung Umi Catering tidaklah begitu bagus, karena biasanya catering merupakan tempat pemesanan makanan saja, bukan seperti jenis restaurant yang mengandalkan makanan dan tempat makan itu sendiri. Tempat di Tunjung Asri Catering lebih mirip gudang dan dapur yang dimana penyimpanan makanan dan juga proses pembuatan makanan sesuai dengan pesanan ada di sini. Setelah makanan selesai dibuat, maka akan dikirim langsung menggunakan moda transportasi yang ada.

4. Dalam penelitian ini dilihat pola yang menunjukan tentang bagaimana pengaruh sosial media selalu positif terhadap perkembangan pemasaran dari ke empat informan yang di wawancara. Pengaruh ini sangat berkembang seiring dengan pesat nya perkembangan sosial media jenis apa saja. Trend masyarakat milenial dan juga 
masyarakat modern tidak lepas dari pengaruh sosial media dalam mengisi waktu dan mengisi informasi yang aktual dan cepat. Hal ini rupanya yang mampu narik minat para informan dalam memasarakan produk nya di awal perjalanan meniti karir sebagai penjual makanan.

Untuk pertanyaan yang mempermasalahkan bagaimana pengaruh sosial media selalu positif terhadap perkembangan pemasaran dari ke empat informan yang di wawancara. Pengaruh ini sangat berkembang seiring dengan pesat nya perkembangan sosial media jenis apa saja. Trend masyarakat milenial dan juga masyarakat modern tidak lepas dari pengaruh sosial media dalam mengisi waktu dan mengisi informasi yang aktual dan cepat. Hal ini rupanya yang mampu narik minat para informan dalam memasarakan produk nya di awal perjalanan meniti karir sebagai penjual makanan.

Selanjutnya mengenai bagaimana pengaruh sosial media terhadap pendapatan dari catering ini suadah mulai menandakan dari pola jawaban sangat berpengaruh positif. Pendapatan informan meningkat semenjak memakai sosial media Instagram dalam memasarkan produk andalan mereka. Pendapatan meningkat drastis dari pada mengunakan cara konvensional semacam promosi mulut ke mulut untuk memasarkan produk makanan catering

Jawaban yang positif juga ditemukan dari pertanyaan mengapa pelanggan memilih untuk memakai Instagram. Pengaruh positif itu muncul dari kepopuleran Instagram, kemudahan menggunakan Instagram dan juga kecanggihan dari Instagram dalam mengkoneksikan para pengguna nya, bisa menggunakan Hashtag, DM (Direct Message) dan fasilitas Cari. Dan yang terakhir pernyataan informan dari pertanyaan apakah ada cara sederhana lain untuk mempromosikan usaha catering yang dijalani, jawaban nya beragam dari hal masih seputar akan mengembangkan ke media yang berbayar selain sosial media yang gratis.

5. Tunjung Asri Catering juga memiliki driver atau pengantar makanan karena pesanan catering sudah pasti akan diatar ke tempat kustomer inginkan. Disamping itu juga ada tukang untuk membeli bahan makanan mentah yang siap diolah oleh tukang masak dari Tunjung Asri Catering. Total untuk pekerja tetap dari Tunjung Asri Catering adalah sebanyak 8 orang. Jumlah ini bisa bertambah seiring dengan besarnya acara yang akan dibuat dan tergantung kustomer sendiri. Biasa nya untuk acara penikahan yang jumlah porsi nya mencapai 500 porsi, dibutuhkan tenaga extra sebanyak 10 orang untuk 
menjadi waiter/waitress dan juga tambahan 4 orng tukang masak dan juga 1 orang driver.

Boga Kerti Catering, Chika Catering dan juga Warung Umi belum memiliki driver atau pengantar makanan karena pesanan catering. Boga Kerti Catering biasanya menyewa kendaraan. Disamping itu juga ada ada tukang untuk membeli bahan makanan mentah yang siap diolah oleh tukang masak. Total untuk pekerja tetap dari Boga Kerti Catering, Warung Umi dan Chika Catering adalah sebanyak 6 orang. Jumlah ini bisa bertambah seiring dengan besarnya acara yang akan dibuat dan tergantung kustomer sendiri. Biasa nya untuk acara penikahan yang jumlah porsi nya mencapai 400 porsi, dibutuhkan tenaga tambahan sebanyak 15 orang untuk menjadi waiter/waitress dan juga tambahan 4 orng tukang masak dan juga 1 orang driver.

6. Proses adalah suatu prosedur, mekanisme dan aliran aktifitas yang dilakukan oleh pelanggan dan juga dimana jasa disampaikan. Dalam penelitian ini akan dijelaskan tentang bagaimana alur yang dibuat oleh pemilik catering dalam menjual produk nya. Proses yang digunakan dalam penelitian ini untuk akun instagram Tunjung Asri Catering, Chika Catering, Boga Kerti Catering dan juga Warung Umi Catering adalah hampir sama. Pemahasan selanjut nya adalah bagaimana ke empat catering tersebut mengadakan proses untuk catering yang dipakai.

a. Proses pertama adalah calon pembeli melihat gambar yang ada di akun ke empat catering tersebut. Akun catering telah terlampir nomer telepon, alamat dan juga gambar makanan beserta deskripsi makanan nya. Biasa nya pembeli melihat dan juga berinteraksi langusung di akun Instagram tersebut, ataupun melalui nomer telepon yang sudah tertera di masing-masing akun Instagram. Proses melihat ini menjadi sangat penting karena ini merupakan pandangan pertama yang bisa dilakukan calon pembeli dan juga bagi penjual, gambar yang menarik harus digunakan agar menarik minat pelanggan secara simultan.

b. Setelah calon pembeli melihat dan berinteraksi dengan penjual bagaimana prosedur pemesanan nya, calon pembeli akan mengutarakan niat nya untuk memesan berapa porsi dan juga waktu dan tempat yang harus disiapkan. Proses interaksi dengan penjual ini juga terkadang terselip negosiasi harga supaya calon pembeli mendapatkan hasil yang maksimal dengan dana yang minimal.

c. Proses terakhir adalah pembayaran Down Payment (DP) bagi pelanggan yang ingin memesan produk. Biasanya DP dilakukan oleh pelanggan yang notabene 
membeli produk jenis prasmanan untuk acara pernikahan, ulang tahun maupun acara seremonial lainnnya. Jumlah DP yang diberikan untuk Boga Kerti Catering dan Tunjung Asri Catering adalah 20\%, dan jumlah DP untuk Warung Umi dan Chika Catering adalah 25\%. Sisa nya akan dibayarkan pada akhir acara. Untuk produk nasi kotak, snack dan juga nasi tumpeng, pembayaran biasa nya dilakukan di awal transaksi.

d. Proses terkhir setelah ada kesepakatan harga, waktu, jumlah pesanan dan tempat, maka selanjutnya adalah melakukan pengirimana makanan sesuai dengan pesanan dari pelanggan. Pengiriman ini biasa nya didasari dari jarak yang dilakukan. Apabila masih di wilayah Denpasar, maka tidak ditambahkan biaya pengiriman. Apabila diluar wilayah Denpasar, maka akan dikenakan biaya tambahan. Adapun biaya tembahan untuk transportasi di ke empat catering ini adalah sejumlah 150 ribu rupiah.

7. Psysical Evidence disini bermakna dari kualitas dari akun instagram, bagaimana memanajemen gambar dan juga membalas pesan yang dari pelanggan. penampakan nyata dari catering biasa nya ada di penampilan produk, tata hiasan dan tata hidangan untuk membuat pelanggan puas dengan layanan yang diberikan. Disamping itu juga akun Instagram yang atraktif dan juga sarat informasi menunjang sisi positif dari Psysical Evidence di bisnis catering. Seperti teori Zeithaml and Bitner yang dikutip oleh Ratih Hurriyati (2005) pengertian dari Psysical Evidence adalah merupakan suatu hal yang secara turut mempengaruhi keputusan konsumen untuk membeli dan menggunakan produk jasa yang ditawarkan. Dari Teori tersebut sudah bisa dipastikan pemilik catering harus memperhatikan hal yang tampak agar bisa menarik minat pelanggan.

\section{PENUTUP}

Berdasarkan hasil penelitian yang dilakukan terhadap empat jumlah akun catering yan mengunakan sosial media Instagram yang mana memiliki follower lebih dari 1000 yang ada di Denpasar Bali mendapatkan kesimpulan sesuai dengan rumusan masalah nya yaitu dalam menggunakan strategi Marketing Mix, semua informan yang diwawancarai sudah memperhatikan dan juga sudah menggunakan teori tersebut dan di implementasikan dengan sebaik-baik nya Penggunaan sosial media Instagram untuk mempopulerkan dan mempromosikan produk catering di dunia maya, terbilang efektif dan juga menghasilkan 
tambahan pendapatan dari informan. Semua informan juga mengatakan bahwa penggunaan strategi pemasaran menggunakan Instagram lebih bermanfaat daripada menggunakan cara konvensional lain nya.

Berdasarkan kesimpulan diatas, kontribusi teoritis nya adalah semakin berpengaruh positif nya media sosial terutama Instagram dalam memasarkan dan mempopulerkan suatu produk. Hal ini disebabkan karena berkembang nya gawai pintar dan penggunaan internet di kalangan masyarakat. Selain itu, pemilihan sosial media Instagram juga didasari dari kepopuleran media sosial tersebut, fasilitas yang lengkap dan juga tampilan yang atraktif untuk menawarkan produk makanan.

Kontribusi Praktis dari penelitian ini adalah akan mengedukasi pemilik bisnis serupa untuk tidak lagi ragu menggunakan sosial media terutama Instagram yang dimana sudah terbukti dengan penggunaan Instagram dalam pemasaran produk makanan catering di Denpasar Bali, hasil nya positif dan juga mampu menambah pendapatan bagi pemilik bisnis makanan catering. Kontribusi kebijakan yang bisa ditimbulkan dari penelitian ini masih belum ada, karena untuk pemerintah Indonesia melalui Kementrian Kominfo tidak melarang masyarakat untuk menggunakan media sosial untuk menawarkan dan mempopulerkan suatu produk. Maka tidak ada hambatan dari pemerintah pusat maupun pemerintah daerah untuk menggunakan aplikasi sosial media Instagram ini.

Suatu fenomena atau permasalahan dalam bidang ilmu managemen tidak akan mungkin sepenuhnya akan dipahami dan diselesaikan berdasarkan satu penelitian. Sehingga disini perlu untuk melakukan penelitian ulang dan research mendalam terhadap penelitian ini apabila ingin dikembangkan lagi. Saran penulis untuk calon penulis penelitian yang hampir mirip dengan penielitian ini adalah lebih memperluas jangkauan bisnis catering seperti di setiap kabupaten di Provinsi Bali, ataupun di daerah lain semisal di Surabaya atau Bandung. Maka dari itu pula , akan membuktikan bahwa pengaruh media sosial tidak tergantung terhadap suatu daerah saja, namun juga kemungkinan bisa diaplikasikan di seluruh Indonesia. 


\section{DAFTAR PUSTAKA}

Adnyana, R., and Darma, G.S. (2015). Strategi Marketing Mix, Yield Management, Customer Satisfaction and Occupancy Rate, Jurnal Manajemen \& Bisnis, 12 (1): 92-115.

Agung, N.F.A., and Darma, G.S. (2019). Opportunities and Challenges of Instagram Algorithm in Improving Competitive Advantage, International Journal of Innovative Science and Research Technology, 4 (1): 743-747.

Arsriani, I.A.I., and Darma, G.S. (2013). Peran Media Sosial Online Dan Komunitas Terhadap Keputusan Nasabah Bank, Jurnal Manajemen dan Bisnis, 10 (2): 48-68.

Andreas, K.M., Haenlein Michael. (2010). Users of the world, unite! The challenges and opportunities of social media, Business Horizon, 53 (1): 61.

Atmoko, B.D. (2012). Instagram Handbook, Tips Fotografi Ponsel. Jakarta: Media Kita.

Baker, G . (2000). Marketing Management: Twelved Edition. New York: MC. Grawhill Inc.

Boyd, H.W. (2000). Manajemen Pemasaran, Edisi Kedua. Jakarta: Erlangga.

Carmen, B. (2017). Nike On Instagram: Themes of Branded Content and Their Engagement Power, Jurnal Internasional, CBU International Conference on Inovation Science and Education. Czech Republic.

Carr, C.T., and Hayes Rebecca A. (2015). Social Media: Defining, Developing, and Devining, Atlantic Journal and Comunication, 26 (7): 88.

Darma, G.S. (2004). Qualitative and Quantitative Data in Management Research: A Study of the Banking Industry, Jurnal Ekonomi \& Bisnis, 16 (2): 107-118.

Darma, G.S. (2006). Mobile Marketing: Sebuah Strategi Keunggulan Bersaing Online. Denpasar: Undiknas Press.

Darma, G.S. (2018). Seuntai Pesan, Menjawab Zaman. Indonesia: Pustaka Larasan Press.

Darma, G.S. (2019). Kacamata Media, Kesuksesan Bersyarat. Indonesia: Pustaka Larasan Press.

Darma, G.S., Apollo, A., Rusmanda, G., and Umar, Y. (2019). Digital Education 4.0. Indonesia: Cakra Media Utama Press.

David, D. (2002). Manajemen Agribisnis, Buku Keempat. Jakarta: Erlangga.

Haryani, I. (2015). Strategi Komunikasi Penggunaan Media Sosial Sebagai Media Promosi Band Indie Mustache and Beard, Jurnal Ilmiah, Program Studi Ilmu Komunikasi, Fakultas Komunikasi dan Bisnis, Universitas Telkom, 30 (50): 67-68.

Handika, M.R., Maradona, A.F., and Darma, G.S. (2018). Strategi Pemasaran Bisnis Kuliner Menggunakan Influencer Melalui Media Sosial Instagram, Jurnal Manajemen \& Bisnis, 15 (2): 188-199. 
https://formaxmanroe.com/threads/pengertian-catering-secara-lengkap.6519/ diakses pada tanggal 24 Januari 2018.

https://pakarkomunikasi.com/pengertian-media-sosial-menurut-para-ahli diakses pada tanggal 3 Maret 2018 , pukul 22.48.

https://informasiana.com/pengertian-globalisasi-menurut-ahli/ diakses pada tanggal 5 Maret 2018 , pukul 14.31

Kanten, I.K., and Darma, G.S. (2017). Consumer Behaviour, Marketing Strategy, Customer Satisfaction, and Business Performance, Jurnal Manajemen \& Bisnis, 14 (2): 143-165. Kotler, P., and Armstrong. (2004). Dasar-dasar Pemasaran, Edisi Kesembilan. Jakarta: PT. Indeks.

Kotler, P., and Gary Armstrong. (2012). Prinsip-Prinsip Pemasaran, Edisi 13. Jilid 1. Jakarta: Erlangga.

Kusnadi, D.S., and Darma, G.S. (2018). Menakar Implementasi Green Marketing Pada Usaha Kecil Menengah, Jurnal Manajemen \& Bisnis, 15 (1): 1-18.

Kietzmann, J.H. (2011). Social Media? Get Serious! Understanding the Functional Building Block of Social Media, Business Horizon , 241-251.

Lebas, Y.N. (2017). Komodifikasi di Era Masyarakat Jejaring: Studi Kasus Youtube Indonesia, Jurnal Ilmiah, Departemen Sosiologi , FISIP UI, 62 (3): 77.

Maharani, I.G.A.P.D., and Darma, G.S. (2018). Consumer Purchasing Behavior Analysis on Impulse Buying, Jurnal Manajemen \& Bisnis, 15 (3): 16-37.

Moriansyah, L. (2015). Pemasaran Melalui Media Sosial: Antecedents dan Consequenses, Jurnal Ilmiah, Fakultas Ekonomi dan Bisnis Universitas Indonesia.

Magdalena, H. (2017). Customer Engagement with A Brand In The Context of Social Media, Jurnal Internasional, CBU International Conference On Inovation Science And Education, Czech Republic 30 (1): 88.

Milles, M.B., and Huberman, M.A. (1984). Qualitative Data Analysis. London: Sage Publication.

Pranata, I.M.A., and Darma, G.S. (2014). Strategi Penerapan E-Commerce Dalam Meningkatkan Keunggulan Bersaing, Jurnal Manajemen \& Bisnis, 11 (1): 69-81.

Putri, V.K.A. (2015). Media Sosial Terintegrasi dalam Komunikasi Pemasaran Brand : Studi Komparasi Pemanfaatan Media Sosial oleh High dan Low Involvement Decision Brand, Jurnal Komunikasi Indonesia, IV.

Ratih, H. Strategi Komunikasi Pemasaran Kripik Maicih di Twitter, Jurnal Ilmiah, Program Studi Komunikasi, Universitas Telkom, 60 (2): 10. 
Setyawati, T., and Darma, G.S. (2018). Efektifkah Experiential Marketing di Sebuah Rumah Sakit ?, Jurnal Manajemen \& Bisnis, 15 (1): 160-175.

Stanton, W. (2002). Prinsip-Prinsip Pemasaran, Terjemahan oleh Alexander Sindoro. Jakarta: Erlangga.

Tampubolon, M. (2016). Strategi Promosi Coffee Shop Melalui Media Sosial Instagram (Studi Deskriptif pada akun @crematology), Jurnal Ilmiah, Prodi S1 Ilmu Komunikasi, Fakultas Ekonomi dan Bisnis, Universitas Telkom.

Tjiptono, F. (2002). Manajemen Jasa. Yogyakarta: Andi. 